\title{
Vindicating Service Quality of Education through Structural Equation Modeling (SEM): International Students' Perspective
}

\author{
Abu Rashed Osman ${ }^{1}$, Abu Saleh Md. Sohel-Uz-Zaman ${ }^{1}$, Mohammad Ali Ashraf ${ }^{1} \&$ Aslam Uddin ${ }^{2}$ \\ ${ }^{1}$ United International University, Dhaka \\ ${ }^{2}$ Bangladesh University of Business \& Technology, Dhaka \\ Correspondence: Abu Rashed Osman, United International University, Dhaka.
}

Received: November 26, 2019

Accepted: March 18, 2020

Online Published: March 20, 2020

doi:10.5430/ijhe.v9n3p158

URL: https://doi.org/10.5430/ijhe.v9n3p158

\begin{abstract}
The prime objective of this paper is to identify the factors that influence service quality of education mediating by institutional image in tertiary education perspective. To reach this aim, the Nordic model was applied as a theoretical base of the study. Program quality as a technical quality as well as industrial link and student satisfaction as functional quality were postulated to positively influence image toward the service quality education. Data $(n=294)$ were collected from foreign students studying at University Utara Malaysia located in northern Malaysia through convenient sampling procedure. The structural equation modeling (SEM) was utilized for analyzing the data. Analysis of the data indicates that image has a full mediating role in the relationship between industrial link and service quality education. To uphold service quality in education, the academic authorities need to nurture earnestly industrial link and image of the institution because image occupied full mediation role between industrial link and service quality of education. Moreover, program quality and student satisfaction have shown direct significant impact on image and service quality of education and can be regarded as critical factors for certifying image and service quality in higher education. The conceptual model of this study would give more recognition if any tertiary level institution addresses this in order to increase their image and overall ranking. This study incorporated institutional image as a mediating variable, which is an outstanding effort in tertiary level studies for inspiring existing body of literature in perspective of international students.
\end{abstract}

Keywords: service quality, program quality, student satisfaction, industrial link, institutional image

\section{Introduction}

In Malaysia, the highest proportions of international students are prosecuting their higher educations, and the nation had transformed as the quickest emergent destination for the overseas students over the previous decade; and the student growth per annum is more than sixteen percent (The Daily Sun, 2015). As predicted the country in the way of accomplishing the target of inviting two hundred thousand international applicants by 2020 which is very much consistent with the Malaysian aim of emerging as and international and regional education center (Yeoh, 2016).

To attain this objective, Malaysian authority has been concerned with enhancing the quality and the overall image of the post-graduate education in the higher academic institutes of Malaysia.

Therefore, in order to stay relevant and to compete in the global market and deliver high quality education service according to the assessment from clients-perspective of the students who are the prime customers in this respect Malaysia has shifted from manufacturing economy to knowledge economy (Yeoh, 2016). Thus, the measuring of service quality is a crucial concern in attracting the international students for higher studies in Malaysia. A recent research confirms that "quality" continues as the highest competitive priority among delivery, flexibility, and cost (Naqshbandi \& Idris, 2012).

Hence, the purpose of this study is to investigate the dynamics of service quality comprising the explanatory variables of program quality, links with industry and the satisfaction of students which have the potential influence on the service quality of education through the mediating impact of overall image of the respective institutions among the foreign students studying in Malaysia. In order to attain this objective, a theoretical framework using the Nordic Model by Grönroos (1984), and the SERVEQUAL model by Parasuraman, Zeithaml, and Berry (1985) has been proposed. By using measurement scales which have been created to measure various aspects of academic 
program quality, industrial link, and institutional image, a survey tool was developed to assess the various relationships as implied in the framework.

It is presumed that this study would contribute in understanding what foreign students expect as the prime customers of the higher education and how to enhance the quality of education service in satisfying their needs. Evidences suggest that little research has been done considering image-factor as mediating variable to put an influence on service quality in Malaysian higher education institutes. Hence, this study will help to fill up this gap in order to measure the influences of afore-mentioned variables on service quality education through the mediating variable of the overall image of the Malaysian universities. This paper has been organized in several sections. Firstly, a brief theoretical review containing relevant literatures on the variable enlisted in the framework; secondly, research model and hypothesis; thirdly, a discussion on research method and findings from the data analyses. At last the paper was concluded with a discussion of the meaning of the results and their implications.

\section{Theoretical Foundations and Past Research}

The Nordic model is the leading endeavor that measures quality of service (Ghotbabadi, Baharun \& Feiz, 2012). This initial conceptualization was constructed by Grönroos $(1982,1984)$. Grönroos $(1982,1984)$, defines service quality by two variables: technical and functional quality; technical quality explains what are received by consumers, and functional quality explains how the service is received by consumers which are mediated by the factor of image. This model is considered to be a common structure which is not limited to only two methods of quality because there is no common understanding as to the characteristics or components of service quality dimensions (Brady \& Cronin, 2001). Nonetheless, there is a broad perception that service quality is a multifaceted or multi-attributed construct (Kang \& James, 2004; Grönroos, 1990 and Parasuraman et al.1985, 1988). Even though the recent studies on service quality are apparently concentrated on the service delivery method, however it is suggested by European scholars to consider other additional aspects too. For example, Grönroos (1990) and Brady \& Cronin (2001) notified that according to the customer perception there are three dimensions: functional or process dimension, technical or outcome dimension and image.

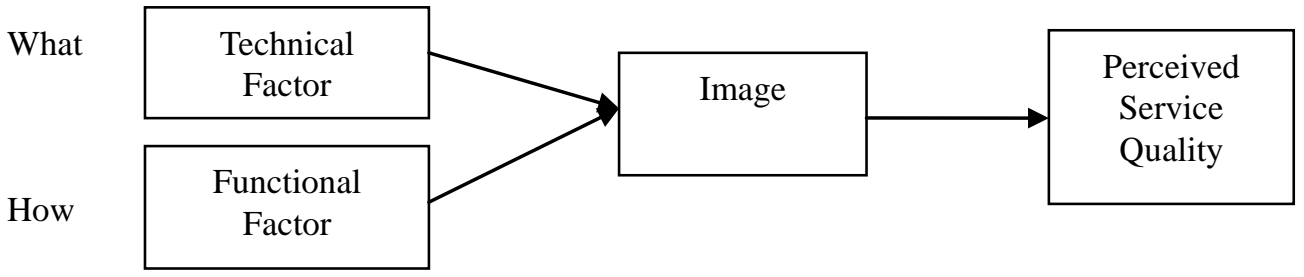

Figure 1. The Nordic Model of Service Quality, Source: Grönroos (1984)

The image of a business entity is the cumulative of images and expectations in the mind-set of individuals (Marič, Pavlin \& Ferjan, 2010). The corporate images are the practical exposures, convictions, feelings, wisdom and perceptions that people conceive regarding an organization (Arpan, Raney \& Zivnuska, 2003). Thus, it is a collective process by which customers compare and contrast various organizations and build an impression about those organizations based on their experiences, convictions, and feelings (Palecio, Meneses \& Pérez, 2002). Institutional image is termed as the total reflection created on the minds of the people regarding a business entity (Kotler \& Fox, 1995). It is interconnected to a several physical and behavioral characteristics of the organization such as; name of the organization, architecture, products/services portfolio, ritual, philosophy, and to the perception of quality conveyed by everyone intermingling with the organization's clients.

By examining the service quality Parasuraman et al. (1985) defined service quality as the comparative analysis between the expectation of customers and perception of service. Based on the previous studies on service, they further suggested SERVQUAL is a specific mechanism for assessing service quality (Parasuraman et al., 1988). Regarding the usefulness of SERVQUAL Tahir \& Ismail (2005) found that it (SERVQUAL) has been implemented successfully in various settings. Parasuraman et al. (1998) declared that SERVQUAL models had been designed in such a way so that it is applicable across the wide range of services, therefore, this model could be improvised according to specific requirements. SERVQUAL is regarded as the most persistent, admired, maximum cited and top research mode of evaluating service quality among other similar models (Ashraf, 2014; Waugh, 2002). The advantage of SERVQUAL is that it is a proven instrument as that can be used comparatively for benchmarking purposes (Brysland \& Curry, 2001). In this research the five dimensions of SERVQUAL: reliability, responsiveness, empathy, assurance and tangibles, proposed by Parasuraman et al. (1985) have been accommodated to assess the service quality of education for overseas students. 


\subsection{Institutional Image}

The image of the institution is an uncompromising factor because it defines the richness of the program, influences students to get admission, enhances retention, and manages financial aid prospects. The contemporary literature is not strong enough to clarify the image materialization procedures in the perspective of higher education sector (Gallifa \& Batalle, 2010). Students' perceptions about institutional image are imperative since it outlines students' understandings of the strong footing of an institution in the market. Subsequently, image is the reflection of quality education and a straight forward indication for a student to appraise its programs, services and overall worth of higher education (Parves \& Ho, 2012).

Competitiveness is an additional feature which is decontaminated with the worth of image in the institutional platform. Due to the increasing capability in international education, academic institutions are highly tied up in developing a distinctive image with the intention of reaching a competitive advantage (Arambewela, \& Hall, 2006). As stated by the Gestalt theory, institutional image is normally visualized about competent teaching staff, syllabus quality, teaching quality, and tuition-quality relationship (Alves \& Raposo, 2010). Arpan et al. (2003) recognized three unwavering aspects that influence image: academic attributes, healthy attributes and mass media reporting yet only academic attributes were found consistent across groups.

\subsection{Program Quality}

Program quality or curricula structure quality is an important attribute of education in terms of service provided to the students and also institutional image of higher education for which meritorious overseas students are interested to get that academic service (Ashraf, Osman \& Ratan, 2014; Osman \& Ashraf, 2014). The highest ranking universities around the world offer the best quality education programs and maintain organizational collaborations which are influential for individual's decision making about admission in the specific program (Kazoleas, Kim \& Moffitt, 2001). Thus, higher educational institutions require to ensure that the education service they offer conform to the students' expectations (Hénard \& Roseveare, 2012). However, since quality academic program in higher education is important for student's learning, the farseeing vision of higher education institutes and appropriate strategy must be congruent with research and innovations in teaching and learning (Osman \& Ashraf, 2014; Ashraf, Yusnidah \& Joarder, 2009). The affiliation between study-program quality and image has scanty research evidence. Hegelsen and Nesset (2007) precisely studied the effect of program quality on image of the university college in the Scandinavian region. The findings of this research established that there was a strong correlation between these two variables.

\subsection{Industrial Links}

Graduating students are getting into such a work environment which is distinguished by more and more uncertainty, speed, risk and cross-disciplinary opportunity of working atmosphere (Hénard \& Roseveare, 2012). So, tertiary educational institutions emphasized more not only on the preparation of the students to prove their worth in the new environment but also to learn how they are associated with business and industry.

As a matter of fact, tertiary education institutions are complex organizations which used to face a variety of challenges to have industrial links and at the same time they experience huge pressure from different angles (Hénard \& Roseveare, 2012). In this complex and uncertain atmosphere, institutions have to more careful to adapt with this new environment in order to espouse the principles of quality education. Practically, institutions are to be prepared to learn how they can better serve the student community. At the same time, students have to be the focal point in terms of learning, because project-based learning particularly considered an important weapon by which students can help institutions in responding to the upcoming challenges of the new environment (OECD, 2012).

In this regard, Hénard \& Roseveare (2012) confidently suggest that higher education institutes need to prepare the students to cope with this new environment with their proper skills, knowledge and moral values. There has been an ample opportunity of the new graduates to build and recreate knowledge with practical experience in their working life reformulating theories of knowledge in practical learning environment. This process requires a strong link between business and industry which can enhance image of the respective institutions as well (Hegelsen \& Nesset, 2007). Therefore, strong linkages between academic projects and working life open genuine avenues to equip the students with both generic and professional competencies and to set up networks for impending employment after graduation (Hénard \& Roseveare, 2012).

\subsection{Student Satisfaction}

In general, the fact is that students' satisfaction is strongly associated to reputation and image which is in the line with perceived service quality in the higher education sector (Osman \& Ashraf, 2014). Recently, Weerasinghe and Farnando (2017) defined students' satisfaction as: 'a temporary approach causing from an appraisal of students' 
academic experience, services and facilities". Satisfaction is an emotive likeness to a product or service know-how (Spreng \& Singh, 1993). At present, satisfaction awareness has been overstretched in in respect of higher study. In few studies it has been advocated that student satisfaction is a difficult conception, embracing several items (Richardson, 2005). Student satisfaction is reviewed by the outlooks of the students and their insights regarding the quality of service provided to them (Babaei et al., 2015). Students create positive sentiments about the academic institution and feel honored to recommend the same to new students once they are satisfied.

\section{Research Model and Hypotheses}

The conceptual model that has been accommodated in the endeavor, shown in Figure 2, is constructed on the Nordic Model framed by Grönroos (1984). In this model, service quality of education is the dependent variable, which is mediated by the institutional image for identifying the impacts of program quality, industrial links and student satisfaction.

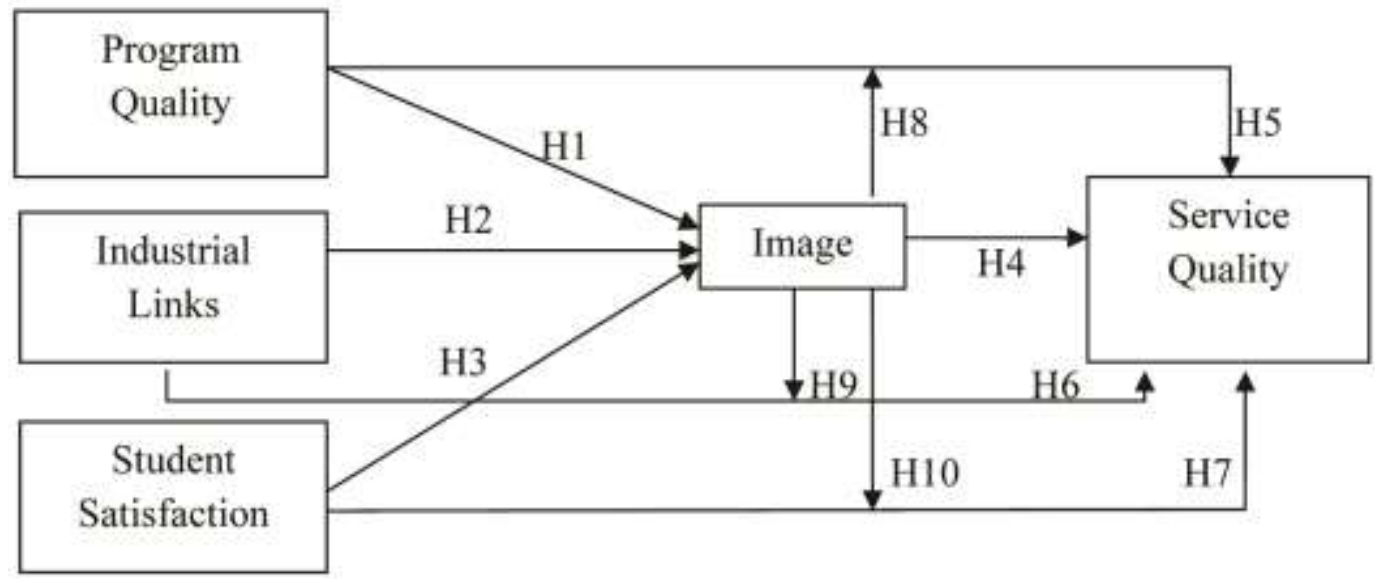

Figure 2. Research Model of Service Quality of Education

There are seven hypotheses in the proposed model. Every single hypothesis is generated from the existing literatures on dissimilar variables and articulated on the basis of major construction of the Nordic model. As mentioned it previously that, program quality has a substantial influence that consequently influence the service quality of the academic program. A number of empirical and conceptual analyses on service quality in higher education endorse that the program quality dimension affects institutional image (Abdullah, 2006; Ko \& Pastore, 2005). Therefore, based on those studies, it is hypothesized that:

\section{H1: Program quality has a statistically significant positive consequence on institutional image.}

There have been few concepts introduced by evolutionary experts in industrial economics, such as the 'Triple Helix' concept which is grounded on the inventive knowledge economy. In the Triple Helix model, has recognized institution of higher education, industry, and government, etc. as the first major institutions in the knowledge economy (Etzkowitz \& Leydesdorff, 1995), which intuitively means an 'entrepreneurial university'. According to Cooke (2002), academic institution's commitment is to ensure its knowledge-base, virtually would enhance the image of the institution.

As number of benefits that a university would enjoy from this triple helix model; these are: reliability, honor, appreciation, earning from consultancy, access and scope of faculty and graduate students to the innovative projects (Macpherson \& Ziolkowski, 2005). These innovated projects bring about the social reputation or high entrepreneurial image through the industry link. Thus, the industry linkage enhances an entrepreneurial spirit and creates the highest level of institutional image. Therefore, it can be hypothesized that:

\section{H2: Industrial link has a significant positive effect on institutional image.}

Until now, extensive research has been conducted on the relationship in between customer satisfaction and corporate image (Hegelsen \& Nesset, 2007; Hu, Kandampully \& Juwaheer, 2009; Parvez \& Ho, 2012). Hu et al. (2009) tried to ascertain the affiliation that exist in between quality of service and perceived value, and how they influence the satisfaction of customer, image of the organization and behavioral intentions. This model enlightens that superior service quality and premier customer value would be able to satisfy customer profoundly, that would influence firm's 
image and eventually would lead to customer retention. Finally, it is concluded that the client satisfaction has a significant positive influence on firm's image.

Hegelsen and Nesset (2007) analyzed the associations among quality of the service, facilities, student satisfaction of the student, image of the college, and image of the study program, with the loyalty of the student as the ultimate dependent variable. The study underlined the image of the institution and the image of the study program as two distinct concepts. The conceptual model of the investigation indirectly narrates the image of the study program whereas student satisfaction and the image of the institution are directly connected to student loyalty. The degree of satisfaction from each service interaction is considered as having an impact on assessment of image. Student satisfaction invigorates the institution's reputation when students are happy and their holistic mindset towards the institution enhanced. These attitudes then affect the image (Parvez \& Ho, 2012). Johnson, Gustafsson, Andreassen, Lervik, and Cha (2001) stated that confidence and trust are the major contributing factors of corporate image, which are the consequences of satisfaction. Thus, the hypothesis is:

H3: Student satisfaction has a significant positive effect on institutional image.

Institutional image is labeled as the general depiction created in the hearts of the people as regards to an institute (Zainudin, 2010). In this connection, Barich and Kotler (1991) highlight the relationship between image and quality products or service delivery. If a service organization is able to create a positive image in the minds of clients, then negligible errors will be unnoticed by them and their perceived quality will not be distracted (Zainudin, 2010). This means positive impression has an effect on service quality. Arpan et al. (2003) reassured that institutional image has a substantial influence on service quality of education. Thus,

\section{H4: Image has a significant positive effect on service quality of education.}

A number of studies such as Ashraf, Osman and Ratan (2014), Osman and Ashraf (2014), Ko and Pastore (2005), and Hegelsen and Nesset (2007) clearly showed the necessity of program quality which possess substantial positive influence on academic service quality. The dimensions of program quality in the models are defined broadly and compositely by four sub-dimensions: curriculum, academic facilities, relations with industry, and input quality. Like Ashraf, Osman and Ratan (2014) and Osman and Ashraf (2014), Ko and Pastore (2005) pointed out that superior course-design and study materials boost the responsibilities and commitment of students towards learning, which can be assumed an indication of quality in tertiary level education. On the other hand, syllabus must be expressive, worthy, and useful to student's job prospect. Parallel conclusions are also presented in the study of Hegelsen and Nesset (2007) which establish the positive relation in between program quality and service quality. Most recently, Abu, Ruswiati, and Martino (2018) empirically proved that program quality significantly influences service quality of education $(\beta=0.65, \mathrm{p}<0.01)$. Hence,

\section{H5: Program quality has a significant positive effect on service quality of education.}

As stated earlier, industrial link and academic issues are critical to postgraduate students in the reputed university (Robert, Troy \& Phil, 2008). This outcome shows that graduate students primarily prefer to focus about profession through industrial link and consider this effort as an aspect of service quality. There are other studies that found positive interrelationship between industry and university which subsequently improves service quality of education (Rajani, Sangeeta \& Gautam, 2013; Dopson \& Tas, 2004; Gursoy \& Swanger, 2004). In respect of these studies, industrial link has a constructive affiliation with overall service quality. According to this evidence, it is hypothesized that:

\section{H6: Industrial link has a significant positive effect on service quality of education.}

Perceived service quality is demarcated through the customer's emotional evaluation about the superiority or fineness of a product while perceived value is the customer's entire judgment of the usefulness of a product based on awareness of what is gained and what is sacrificed (Zeithaml, 1988). Some empirical evidences suggest that there has been a robust connection between student satisfaction and service quality (Huang, 2009; Albert, Arthur \& Pierre, 2000; Ambrose, Geoffrey \& Thomas, 2014).

Fundamental dimensions of quality are impartially precise whereas satisfaction judgment has an extensive range of dimensions that also embrace quality aspects (Huang, 2009). The customer's entire experiences with the organization is the basis of customer's total satisfaction (Ambrose, Geoffrey \& Thomas, 2014). Parallel to service quality, customer satisfaction can emerge at several levels in an organization which are classified as satisfaction with the dealing person, satisfaction with the core services and satisfaction with the organization in total (Sureschandar, Rajendran \& Anantharaman, 2002). Thus, it can be hypothesized that 


\section{H7: Student satisfaction has a significant positive effect on service quality of education.}

\subsection{Mediation Role of Institutional Image}

To establish mediating role of institutional image, the below listed literature backings have been organized from the extensive literature review.

Several empirical studies support that program quality influencing institutional image (Abdullah, 2006; Ko \& Pastore, 2005). A few other researchers suggest that image influences service quality (Arpan et al., 2003; Zainudin, 2010). Thus, the path can be constructed as such; Program quality $\rightarrow$ image $\rightarrow$ service quality. Several empirical evidences support that industrial links influencing image of the institution (Cooke, 2002; Macpherason \& Ziokowski, 2005). Some other researchers suggest that image influences service quality (Arpan et al., 2003; Zainudin, 2010). Thus, the path can be constructed as such; Industrial links $\rightarrow$ image $\rightarrow$ service quality. Quite a few empirical studies support that student satisfaction has a positive impact on image of the institution (Parvez \& Ho, 2012; Johnson et al., 2001). A number of other researchers suggest that image influences service quality (Arpan et al., 2003; Zainudin, 2010). Thus, the path can be constructed as such; Student satisfaction $\rightarrow$ image $\rightarrow$ service quality. In recent times, Abu et al. (2018) investigated the mediating position of image between student satisfaction, program quality, and service quality and they empirically demonstrated that image fully mediates between student satisfaction and service quality. Therefore, three mediation related hypotheses are created below and logically three paths are in favor of these.

H8: Institutional image mediates between program quality and service quality.

H9: Institutional image mediates between industrial link and service quality.

H10: Institutional image mediates between student satisfaction and service quality.

\section{Research Method}

\subsection{Sampling and Instrument}

In total 450 foreign students were invited to complete an instrument that enclosed several factors of interest. Kline (2011) proposed that total data size ought to be 10 times or higher as large as the number of items (indicators) in the multivariate study. According to the suggestion of Kline (2011), we distributed 450 questionnaires to respondents because this study incorporated 45 items to judge hypotheses. The research instruments were circulated to the foreign students in their respective dormitories by deploying convenient sampling approach. In favor of convenient sampling, Zikmund (2003) suggested that convenient sampling is to be suitable for many responses and it is the finest for exploratory research. Rate of response was just about $65 \%$ accumulated back conforming to 294 replies. A total of 9 responses were found incomplete and these have been amended through median value suggested by (Sekaran \& Bougie, 2010). Finally, 294 datasets were properly analyzed to reach the objective of the study. Research style for this endeavor is a numerical approach purely and data were accumulated through a self-regulated instrument.

The tactic to verifying the conceptual model was constructed on several studies. Measures of service quality education (twenty-two items with five dimensions) were based on a mechanism established by Parasuraman et al. (1985). Measuring items of program quality (seven items) were selected based on Robert et al. (2008). Measures of industrial link (six items) were based on Rajani et al. (2013). Items of student satisfaction (three) and image (three) were based on Ali and Coşkun (2007) and Nguyen and LeBlanc (2001) respectively. The measuring procedure of all items was based on 5-point interval scale of (1)-strongly disagree to (5)-strongly agree. There were four demographic questions also included in the instrument (Table 1) and descriptive statistics for the scale are incorporated in Table 2.

\subsection{Data Adequacy and Normality}

A total of 294 datasets were coded and kept into SPSS version 14 and evaluated by AMOS version 20. A KMO (Kaiser-Meyer-Olkin) index of 0.851 and Bartlett's test of sphericity (sig. at 0.000 ) inferred that the dataset was appropriate for factor exploration. This study also executed univariate normality assessment by Z-scores of skewness statistics and standard error of skewness in addition to kurtosis statistics. The value of Z-score skewness higher than 2 needs to be converted since it is reflected as non-normal data (Hair et al., 2006). The converted variables were then utilized in succeeding CFA and fit models (see Figure 3).

\section{Results and Discussion}

\subsection{Demographic Profile of the Respondents}

Response rate of recurrence of male is $245(83.2 \%)$ and response frequency of female is $49(16.8 \%)$. Respondents are from Master's degree, 129 (44\%), Bachelor's degree, 53 (18\%), and PhDs, $112(38 \%)$. Through the t-test, the study guaranteed that there is no substantial mean difference between male and female responses on service quality of 
education. One more thought-provoking outcome is that undergraduate foreign students are more delighted about quality of education than graduate foreign students.

\subsection{Descriptive Statistics}

Table 1 reveals the uppermost mean (3.95) related with program quality construct followed by image of the institution (3.92) and service quality (3.92). That means the perceptions of respondents are pretty high about these factors. Table 2 also discloses the lowermost mean (3.63) related to industrial link variable implying that respondents' reactions are reasonably not good. This study also endorsed the normality confirmation through skewness and kurtosis. Skewness value must be remained within the range of -1 to +1 and the value of kurtosis -2 to +2 to ensure normal distribution (Geotge \& Mallery, 2010).

Table 1. Descriptive Statistics for Constructs

\begin{tabular}{cccccccc}
\hline Variables & N & Minimum & Maximum & Mean & $\begin{array}{c}\text { Std. } \\
\text { Deviation }\end{array}$ & Skewness & Kurtosis \\
\hline Program quality & 294 & 1 & 5 & 3.95 & .771 & -.087 & -.537 \\
Industrial link & 294 & 1 & 5 & 3.63 & .877 & -.145 & -.558 \\
Student satisfaction & 294 & 1 & 5 & 3.66 & .973 & -.459 & -.495 \\
Image & 294 & 1 & 5 & 3.92 & .927 & -.299 & -.811 \\
Service quality & 294 & 1 & 5 & 3.92 & .881 & -.445 & -.456 \\
\hline
\end{tabular}

\subsection{Reliability Measures}

Confirming Confirmatory Factor Analysis (CFA), the researchers need to judge the uni-dimensionality, validity, and reliability for all constructs prior modeling their inter-relationship (Zainudin, 2012). The given justifications below ensured the evidence of confirmatory factor analysis.

The factor loadings of latent to observed variable should be 0.60 or higher for already established scales to ensure uni-dimensionality (Zainudin, 2012). According to the suggestion of Zainudin (2012), items with factor loadings below 0.60 were removed in order to reach uni-dimensionality and the remaining numbers of items for each construct are as follows: program quality ( 7 to 4 items), industrial link (6 items to 4 ), student satisfaction ( 3 items - no deletion), image ( 3 items- no deletion), and service quality (22 items to 21 ) which is presented in the fit model Figure 3 . In this study, the validity is ensured through convergent validity. The convergent validity can be assessed through AVE. Fornell and Larcker (1981) recommended that reliable variables can have less than 50 percent explained variance (AVE). Thus, the study achieved the convergent validity constructed on the suggestion of Fornell and Larcker (1981). To achieve convergent validity, the composite reliability has been selected. It demonstrates that the level to which several items unfailingly specify the unseen construct. The broadly accepted value is 0.70 or bigger to confirm composite reliability (Hair et al., 2010). The observed value is stretching from 0.78 to 0.94 thus the composite reliability has attained (see Table 2). Cronbach's Alpha value must be 0.70 or higher for ensuring reliability of a measurement model (Hair et al., 2006). This evidence is proved and demonstrated in Table 2. 
Table 2. Reliability, Validity, and Uni-dimensionality Assessment

\begin{tabular}{|c|c|c|c|c|}
\hline Construct & $\begin{array}{l}\text { Factor } \\
\text { Loadings }\end{array}$ & $\begin{array}{c}\text { Cronbach } \\
\text { Alpha }\end{array}$ & $\begin{array}{l}\text { Composite } \\
\text { Reliability }\end{array}$ & $\begin{array}{l}\text { Average Variance } \\
\text { Extracted (AVE) }\end{array}$ \\
\hline Program quality (PQ) & & 0.78 & 0.79 & 0.48 \\
\hline • $\quad$ PQ1 & 0.70 & & & \\
\hline - $\quad$ PQ2 & 0.72 & & & \\
\hline - $\quad$ PQ4 & 0.72 & & & \\
\hline - $\quad$ PQ5 & 0.63 & & & \\
\hline Industrial link (INDL) & & 0.79 & 0.78 & 0.57 \\
\hline - $\quad$ INDL2 & 0.78 & & & \\
\hline - $\quad$ INDL3 & 0.82 & & & \\
\hline - $\quad$ INDL4 & 0.65 & & & \\
\hline - $\quad$ INDL5 & 0.62 & & & \\
\hline Student satisfaction (STUD) & & 0.80 & 0.80 & 0.58 \\
\hline • $\quad$ STUD1 & 0.65 & & & \\
\hline - $\quad$ STUD2 & 0.82 & & & \\
\hline - $\quad$ STUD3 & 0.80 & & & \\
\hline \multicolumn{5}{|l|}{ Image of the Institution } \\
\hline • IMG1 & & 0.81 & 0.84 & 0.64 \\
\hline - $\quad$ IMG2 & 0.76 & & & \\
\hline - $\quad$ IMG3 & 0.87 & & & \\
\hline Service Quality & 0.77 & & & \\
\hline - $\quad$ TANG & & 0.80 & 0.94 & 0.61 \\
\hline - $\quad$ RES & 0.82 & & & \\
\hline - $\quad$ REL & 0.87 & & & \\
\hline - $\quad$ ASSUR & 0.89 & & & \\
\hline - $\quad$ EMPH & 0.91 & & & \\
\hline & 0.86 & & & \\
\hline
\end{tabular}

\subsection{Discriminant Validity}

Making the measurement model free from inessential items, discriminant validity needs to verify between each pair of latent exogenous construct. Respecting achieving discriminant validity, some scholars proposed a starting point value of correlation between two constructs must be 0.85 (Clark \& Watson, 1995; and Kline, 2011), even though others suggest a value of 0.90 (Gold, Malhotra, \& Segars, 2001 and Teo, Srivastava, \& Jiang, 2008) is satisfactory for escaping multi-collinearity. In this endeavor, correlation value of 0.90 was reflected as a standard to grasp the discriminant validity. The discriminant validity is attained since the correlation value between two constructs is lower than the proposed cut-off points (see Table 3).

Table 3. Correlations from AMOS Output

\begin{tabular}{ccccc}
\hline Constructs & PQ & INDL & SATIS & IMG \\
\hline PQ & 1 & & & \\
INDL & 0.64 & 1 & & \\
SATIS & 0.69 & 0.51 & 1 & \\
IMG & 0.62 & 0.50 & 0.61 & 1 \\
\hline
\end{tabular}




\subsection{Confirmatory Factor Analysis (CFA)}

It is an extraordinary device for factor analysis. It has a power to make sure about a variable and its indicators are consistent with the investigator's hypothesizing of the nature of that variable. It is mandatory to ensure uni-dimensionality, validity, and reliability before running the CFA for entire constructs (Zainudin, 2012). In this investigation, uni-dimensionality, validity, and reliability have ensured (see Table 4). The below listed final fit model (Figure 3 ) is assembled after executing the CFA for all constructs.

The factor loadings of latent to observed variable should be 0.60 or more for previously proven scales to make sure uni-dimensionality (Zainudin, 2012, p37). According to the recommendation of (Zainudin, 2012), indicators with factor loading smaller than 0.60 were removed in order to accomplish uni-dimensionality and the remaining numbers of items for each construct are as follows: program quality (from 7 to 5 items), industrial link (6 items to 3), student satisfaction ( 3 items - no deletion), image ( 3 items - no deletion), and service quality (22 items to 21 ) which is presented in the fit model Figure 3.The deleted items are PQ6, PQ7, INDL1, INDL6, and RES1 to achieve the fit indices.

Final Fit Model

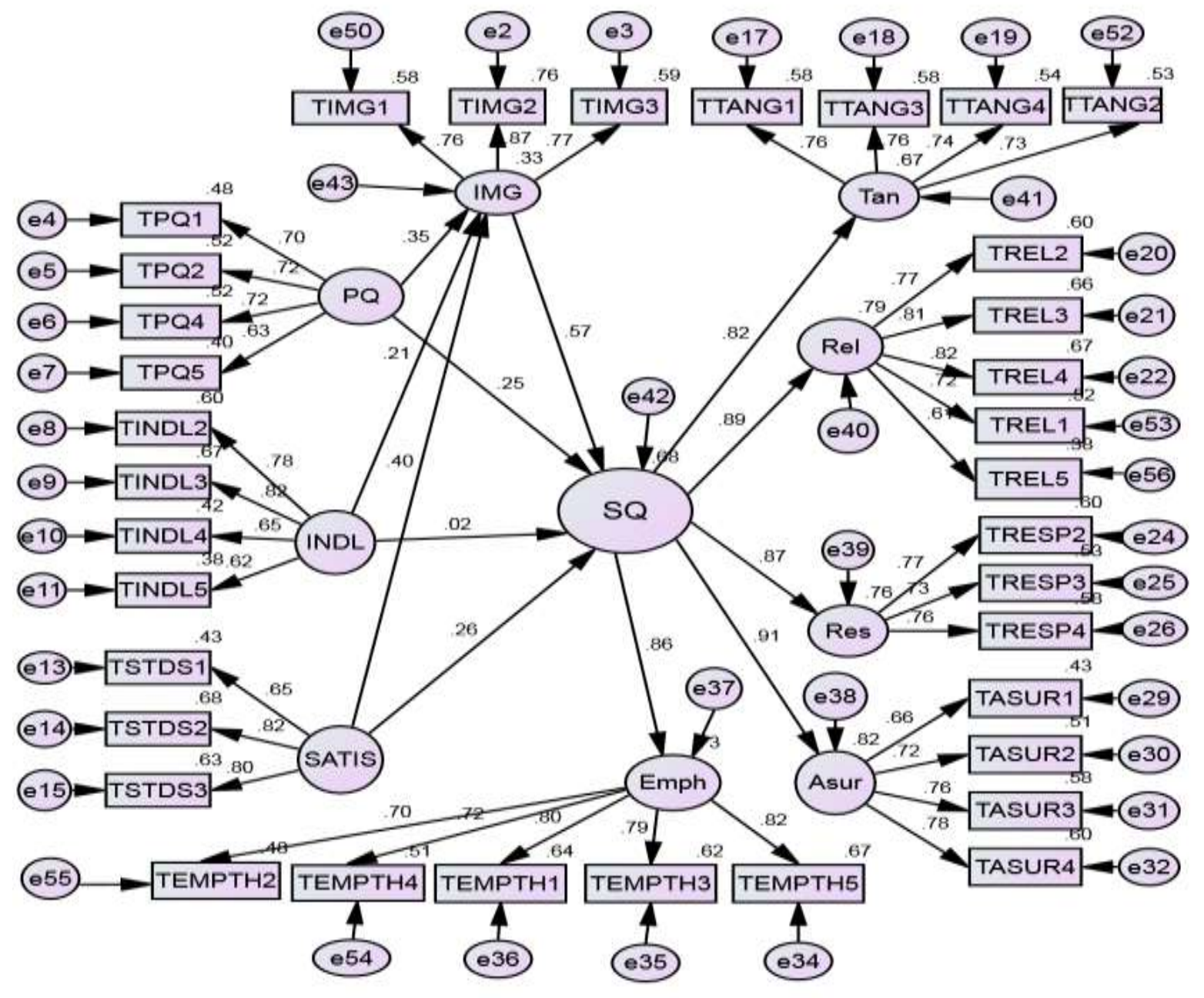

Figure 3. Path Analysis by SEM 


\subsection{Goodness of Fit}

The current study accomplished a good fit of the study model to the data set. Consistent with the references of Hair et al. (1995, 2010) and Holmes-Smith et al. (2006), as a minimum one index from each class will guarantee of model fit. Hence, the goodness of fit was established in this investigation (see Table 4).

Table 4. The Measurement of Appropriateness of Final Fit Model (Figure 3)

\begin{tabular}{|c|c|c|c|}
\hline Name of Category & Index & Acceptable Level & Comments \\
\hline 1. Absolute fit & RMSEA $=0.023$ & RMSEA $<0.08$ & Obligatory level is reached \\
\hline Incremental fit & $\mathrm{CFI}=0.991$ & $\mathrm{CFI}>0.90$ & Obligatory level is reached \\
\hline & $\mathrm{TLI}=0.989$ & TLI $>0.90$ & Obligatory level is reached \\
\hline 3. Parsimonious fit & Chisq/df= 1.089 & $<5.0$ & Obligatory level is reached \\
\hline
\end{tabular}

5.6 Results of Hypotheses

Table 5 presented the statistical significance for various paths by using one-tailed tests, four out of seven paths were statistically significant, two at the $\mathrm{p}<0.05$ level, and two at $\mathrm{p}<0.01$, providing support for $H 1, H 2, H 3, H 4, H 5$, and $H 7$. The estimated model is presented in Figure 4 based on final fit model Figure 3, with adjusted t-statistics and path coefficients recorded in Table 5.

Several past studies have reported that program quality may have impacts on institutional image, but none of these studies have investigated the actual associations between these two variables. This study has demonstrated, at least for this sample, that curricula structure or the overall quality of the program, which is delivered to the students, has an important attention over the image of the higher education institutes in Malaysia. Thus, program quality had a significant impact on institutional image (HI), industrial link had a significant positive impact on institutional image (supported H2). Student satisfaction, in turn, had significant impact on institutional image (H3). The study found a direct relationship between program quality and service quality education (supported H5), although there was a strong relationship between image and service quality, as expected (H4). However, industrial link had no significant relationship with service quality of education (not supported H6). At last, student satisfaction showed a substantial impact on service quality (supported H7). Above mentioned findings demonstrated based on Table 5. The findings of this study are consistent with other reported studies are listed below:

Like Arpan et al. (2003), Dopson \& Tas (2004), and Gursoy \& Swanger (2005), there was a solid link between program quality and institutional image. Like Hu et al. (2009), Parvez and Ho (2012) and Johnson et al. (2001), there was a strong relationship between student satisfaction and image. Like Huang (2009), Albert et al. (2000), Ambrose et al. (2014), and Sureschandar et al. (2002), there was a significant relationship between customer or student satisfaction and service quality. Like Zainudin (2010) and Nguyen and LeBlanc (2001), there was a strong association between image and service quality. The study revealed a positive relationship between program quality and service quality of education consistent with Ashraf, Osman and Ratan (2014), Osman and Ashraf (2014), Ko and Pastore (2005) and Hegelsen and Nesset (2007) and Abdullah (2006. Finally, the study recognized an insignificant positive relationship between industrial link and service quality and this finding is consistent with Cooke (2002) and Macpherson and Ziolkowski (2005) as well as Robert et al. (2008) and Rajani et al. (2013) respectively.

As displayed by Figure 4, program quality, industrial link, and student satisfaction explained 33 percent variation in image means that those three variables are prominent for explaining image. Additionally, in this figure, image clarified 68 percent variation $\left(\mathrm{R}^{2}=0.68\right)$ in service quality of education. As a result, apparently this aspect carries substantial merit to explain service quality and the management of higher institutions must exert more mother-like devotion to cultivate this factor relentlessly for improving service quality. 


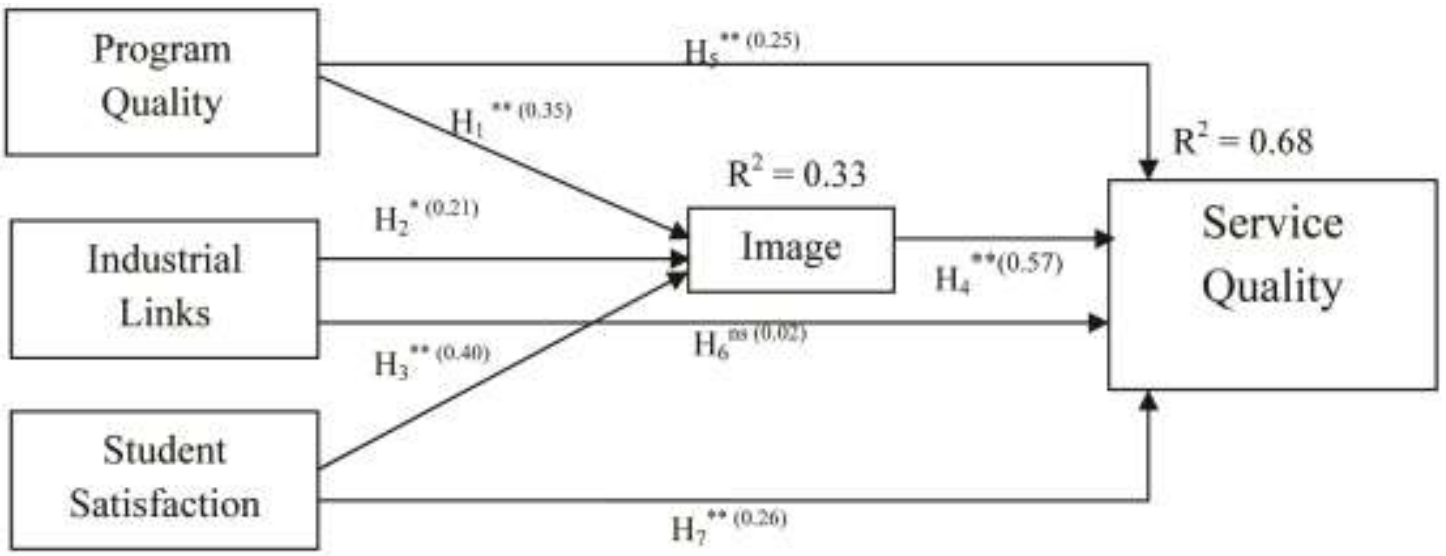

Figure 4. Evaluated Model

Note: $\mathrm{ns}=$ not significant, $*=<0.05$ level and $* *=<0.01$ level

Table 5. Path Analysis and Status of the Hypotheses

\begin{tabular}{ccc}
\hline Path & Path Coefficient & P value \\
\hline H1: Program quality has a positive impact on image** & 0.35 & .002 \\
H2: Industrial link has a positive impact on image ${ }^{*}$ & 0.21 & .033 \\
H3: Student satisfaction has a positive impact on image** & 0.40 & .000 \\
H4: Image has a positive impact on service quality** & 0.57 & .000 \\
H5: Program quality has a positive impact on service quality ${ }^{* *}$ & 0.25 & .002 \\
H6: Industrial link has a positive impact on service quality ${ }^{\text {n.s }}$ & 0.02 & .798 \\
H7: Student satisfaction has a positive impact on service quality** & 0.26 & .007
\end{tabular}

Notes: ** Statistically significant at $\mathrm{p}<0.01 ; *$ statistically significant at $\mathrm{p}<0.05 ; \mathrm{n} . \mathrm{s}-$ not statistically significant.

Table 6. Mediation Status of Hypotheses

\begin{tabular}{|c|c|c|}
\hline Hypothesis & Direct and Indirect Effect & Status \\
\hline \multirow{3}{*}{$\begin{array}{l}\text { H8: Institutional image mediates between program quality and } \\
\text { service quality of education. }\end{array}$} & $\mathrm{PQ} \rightarrow \mathrm{QE}, \beta=0.25, \mathrm{sig}^{* *}$ & \multirow{3}{*}{$\begin{array}{l}\text { Image is not } \\
\text { mediating }\end{array}$} \\
\hline & $\mathrm{PQ} \rightarrow \mathrm{IMG}, \beta=0.35$, sig** $^{* *}$ & \\
\hline & $\mathrm{IMG} \rightarrow \mathrm{QE}, \beta=0.57, \mathrm{sig}^{* *}$ & \\
\hline \multirow{3}{*}{$\begin{array}{l}\text { H9: Institutional image mediates between industrial link and } \\
\text { service quality of education. }\end{array}$} & $\mathrm{INDL} \rightarrow \mathrm{QE}, \beta=0.02^{\mathrm{ns}}$ & \multirow{3}{*}{$\begin{array}{l}\text { Image is } \\
\text { mediating }\end{array}$} \\
\hline & $\mathrm{INDL} \rightarrow \mathrm{IMG}, \beta=0.21, \mathrm{sig}^{*}$ & \\
\hline & $\mathrm{IMG} \rightarrow \mathrm{QE}, \beta=0.57, \mathrm{sig}^{* *}$ & \\
\hline \multirow{3}{*}{$\begin{array}{l}\text { H10: Institutional image mediates between student satisfaction } \\
\text { and service quality of education. }\end{array}$} & STUD $\rightarrow$ IMG, $\beta=0.40$, sig** $^{* *}$ & \multirow{3}{*}{$\begin{array}{l}\text { Image is not } \\
\text { mediating }\end{array}$} \\
\hline & $\mathrm{IMG} \rightarrow \mathrm{QE}, \beta=0.57, \mathrm{sig}^{* *}$ & \\
\hline & STUD $\rightarrow$ QE, $\beta=0.26$, sig $^{* *}$ & \\
\hline
\end{tabular}

Note: Significant at $\mathrm{p}<0.05^{*}$ and $\mathrm{p}<0.01^{* *}$

In this study, the Nordic model served as a useful foundation for explaining service quality of education mediated by image. Here, the direct relationship between program quality and service quality education was supported and similarly indirect relationship between them through image was supported. This implies that image has no mediation between the program quality and service quality education thus H8 is not confirming (see Table 6). Further judging the hypothesis $\mathrm{H} 9$, an interesting result was found that industrial link had no significant impact on service quality directly but indirectly it has impact on service quality. This implies that image has a full mediation role between industrial link and service quality education and earns support against H9. In this respect, image transmits the effect 
of industrial link to service quality of education which is the contributing factor for attracting and retaining international students in the context of Malaysian higher education. In respect of hypothesis H10, image has no mediation role between student satisfaction and service quality of education because student satisfaction has shown direct positive impact on service quality of education. Thus, hypothesis H10 is not sustained.

As per the service quality of education studied, the findings imply that image of a higher educational institute has important direct and indirect concerns for the international students who emigrated from their own countries in order to have a quality education. Additionally, it is observed from this study that for attracting higher education students in any country from outside, program quality, industrial link, and student satisfaction are crucial in improving the status of overall service quality education which evidently supports as with the case of an example of foreign students' attitude toward famous and higher ranking educational institutes in the United States such as Harvard, Stanford, Princeton, MIT etc. Hence, relating this fact, it is confirmed that the technical as well as the functional quality of higher education institutes can enrich quality education service for the students mediating through the image variable.

\section{Practical Implications}

From a practical perspective, as a cumulative body of work on educational service quality emerges, but the conceptual model of this study would give more recognition if any tertiary level institution address this in order to increase their image and overall ranking. A well-understanding of the relationship between program quality, industrial link, student satisfaction, image and service quality that helps to make better policies and strategic decisions as well as it pinpoints the areas to be improved by the management of the institutions. By this way, high quality international students aspired for higher education in the reputed universities of the world can be attracted for scientific research and development.

\section{Direction for Further Research}

Indeed, there are not many studies which include the Nordic model in order to explain service quality with a mediating variable of image. So, more studies will have to be done under this theoretical foundation for testing it in a wide range of situational variations. This study considered only three antecedents to image toward service quality. There may well be others that should be considered in future research, such as other aspects of technical quality. In terms of functional quality, this study also includes only two dimensions such as industrial link and student satisfaction to influence image toward service quality education. Future research could include measures of other dimensions of functional qualities which will be able to explain the functional relationships of those dimensions with image toward service quality as directed by the Nordic model of Grönroos (1984). Besides, dimensions of service quality have been adapted from the study of Parasuraman et al. (1985), which could be avoided to include other items of it to see a variant of results in this respect.

\section{Limitations}

One possible drawback is that the study sample was accumulated from only one public university and respondents were purely international students. In general, students from only one university may not be completely representative of the foreign student-population in Malaysia as a whole because they are located in one region of Malaysia. Therefore, generalization of the outcomes is still questionable. It could have been better results if other universities located in other areas of Malaysia can be included in the survey. The study is absolutely restricted to single public university in Malaysia therefore scopes are open for other public and private universities to conduct further study. In future, the research could be assessed including other participants' reactions based on the conceptual model of this study. Finally, the study used a cross-sectional investigation approach where the data were composed at particular point in time. As a result, it is not realistic for generalization of findings to other tertiary level education contexts.

\section{Conclusion}

The main intent of this endeavor is to recognize the factors that influence service quality of education mediating by institutional image in a higher education perspective. Data analysis confirms that image has a full mediating role in the relation between industrial link and service quality of education. Program quality and student satisfaction have direct positive impact on image of the institution and service quality of education. Then again, industrial link has no direct impact on service quality, the study revealed. Virtually, industrial link should be the concern of leaders in higher education because it has a significant positive impact on image of the institution and also it has an indirect effect on service quality of education. To sustain service quality of education, the academic authorities need to 
cultivate program quality, industrial link, student satisfaction, and image of the institution earnestly for the prosperity of the institutions.

\section{References}

Abdullah, F. (2006). The development of HEdPERF: a new measuring instrument of service quality for the higher education sector. International Journal of Consumer Studies, 30(6), 569-581. https://doi.org/10.1080/01406720500537445

Abu, O., Ruswiati, S., \& Martini, L. (2018). Exploring mediating role of institutional image through a complete structural equation modeling (SEM): A perspective of higher education. International Journal for Quality Research, 12(2), 517-536.

Ali, T., \& Coşkun, O. (2007). Development of a customer satisfaction index model: An application to the Turkish mobile phone sector. Industrial Management and Data Systems, 107(5), 672-687. https://doi.org/10.1108/02635570710750426

Alves, H., \& Raposo, M. (2010). The Influence of University Image on Student Behavior. International Journal of Educational Management, 24(1), 73-85. https://doi.org/10.1108/09513541011013060

Arambewela, R., Hall, J., \& Zuhair, S. (2006). Postgraduate International Students from Asia: Factors Influencing Satisfaction. Journal of Marketing for Higher Education, 15(2), 105-127. https://doi.org/10.1300/J050v15n02_05

Ashraf, M.A., Osman, A.Z.R, \& Ratan, S.R.A. (2014). Determinants of Quality Education in Private Universities from the Students' Perspectives: A Case Study in Bangladesh. Quality Assurance in Education, 24(1), 123-138. https://doi.org/10.1108/QAE-09-2013-0040

Ashraf, M. A. (2014). Quality Life Insurance Service of Jibon Bima Corporation in Bangladesh: An Empirical Study. Industrial Engineering Letters, 4(8), 62-73.

Ashraf, M. A., Yusnidah, I., \& Joarder, M.H.R. (2009). Quality Education Management at Private Universities in Bangladesh: An Exploratory Study. Journal of Education and Educators, 24(1), 17-32.

Babaei, D., Rahimian, A., Omar, Z., \& Idris, K. (2015). Ability mediation effects in the relationship between human resource practices and service quality. Iranian Journal of Management Studies, 8(1), 5-25.

Brady, M. K., \& Cronin, J. J. Jr. (2001). Some new thoughts on conceptualizing perceived service quality: a hierarchical approach. Journal of Marketing, 65, 34-49. https://doi.org/10.1509/jmkg.65.3.34.18334

Chun, R. (2005). Corporate reputation: Meaning and measurement. International Journal of Management Reviews, 7(2), 91-109. https://doi.org/10.1111/j.1468-2370.2005.00109.x

Cooke, P. (2002). Knowledge Economies. London: Routledge. https://doi.org/10.4324/9780203445402

Etzkowitz, H., \& Leydesdorff, L. (1995). The Triple Helix---University-Industry-Government Relations: A Laboratory for Knowledge Based Economic Development. EASST Review, $\quad$ 14, 14-19.

Fornell, C., \& Larcker, D. F. (1981). Evaluating structural equation models with unobservable variables and measurement error. Journal of Marketing Research, 18(1), 39-50. https://doi.org/10.1177/002224378101800104. https://doi.org/10.2307/3151312

Gallifa, J., \& Batalle, P. (2010). Student Perceptions of Service Quality in a Multi Campus Higher Education System in Spain. Quality Assurance in Education, 18(2), 156-170. https://doi.org/10.1108/09684881011035367

George, D., \& Mallery, P. (2010). SPSS for Windows step by step: A simple guide and reference 18.0 update $\left(11^{\text {th }}\right.$ ed.). Prentice Hall Press. Upper Saddle River, NJ, USA.

Ghotababadi, A.R., Baharun, R., \& Feiz, S. (2012). A Review of Service Quality Models. ${ }^{\text {nd }}$ ICM Proceeding. University Technology Malaysia, Malaysia.

Gold, A. H., Malhotra, A., \& Segars, A. H. (2001). Knowledge management: an organizational capabilities perspective. Journal of Management Information Systems, 18(1), 185-214. https://doi.org/10.1080/07421222.2001.11045669

Grönroos, C. (2001). The Perceived Service Quality Concept - a Mistake? Managing Service Quality, 11(3), 150-152. https://doi.org/10.1108/09604520110393386

Grönroos, C. (1990). Service Quality and Marketing. Lexington, MA: Lexington Books. 
Grönroos, C. (1982). Strategic Management and Marketing in the Service Sector. Helsingfors: Swedish School of Economics and Business Administration.

Grönroos, C. (1984). A service quality model and its marketing implications. European Journal of Marketing, 18(4), 36-44. https://doi.org/10.1108/EUM0000000004784

Helgesen, O., \& Nesset, E. (2007). Images, Satisfaction and Antecedents: Drivers of Student Loyalty? A Case Study of a Norwegian University College. Corporate Reputation Review, 10(1), 38-59. https://doi.org/10.1057/palgrave.crr.1550037

Hénard, F., \& Roseveare, D. (2012). Fostering Quality Teaching in Higher Education: Policies and Practices. Institutional Management in Higher Education (IMHE), Paris: OECD Publishing.

Hu, H., Kandampully, J., \& Juwaheer, T. D. (2009). Relationships and impacts of service quality, perceived value, customer satisfaction and image: an empirical study. The Service Industries Journal, 29(2), 111-125. https://doi.org/10.1080/02642060802292932

Ilias, A., Hasan, H. F. A., Rahman, R. A., \& Yasoa, M. R. (2008). Student Satisfaction and Service Quality: Any Differences in Demographic Factors? International Business Research, 1(4), 131-143. https://doi.org/10.5539/ibr.v1n4p131

Johnson, M.D., Gustafsson, A., Andreassen, T.W., Lervik, L., \& Cha, J. (2001). The evolution and future of national customer satisfaction index models, Journal of Economic Psychology, 22, 217-245. https://doi.org/10.1016/S0167-4870(01)00030-7

Kazoleas, D., Kim, Y., \& Moffitt, M.A. (2001). Institutional Image: A Case Study. Corporate Communications: An International Journal, 6(4), 205-216. https://doi.org/10.1108/EUM0000000006148

Kline, R. B. (2011). Principles and practice of structural equation modeling, 3rd edition. The Guilford Press. New York.

Ko, Y. J., \& Pastore, D. L. (2005). A hierarchical model of service quality for the recreational sport industry. Sport Marketing Quarterly, 14(2), 84-97.

Kotler, P., \& Fox, K. (1995). Strategic Marketing for Educational Institutions. Englewood Cliffs, NJ: Prentice-Hall.

Lemmink, J., Schuijf, A., \& Streukens, S. (2003). The role of corporate image and company employment image in explaining application intentions. Journal of Economic Psychology, 24, 1-15. https://doi.org/10.1016/S0167-4870(02)00151-4

Marič, M., Pavlin, J., \& Ferjan, M. (2010). Educational Institutional Image: A Case Study. Organizacija, 43(2), 58-65. https://doi.org/10.2478/v10051-010-0007-0

Macpherson, A., \& Ziolkowski, M. (2005). The role of university-based industrial extension services in the business performance of small manufacturing firms: case-study evidence from western New York. Entrepreneurship and Regional Development, 17(6), 431-442. https://doi.org/10.1080/08985620500385601

Naqshbandi, M. M., \& Idris, F. (2012). Competitive priorities in Malaysian Service Industry. Business Strategy Series, 13(6), 263-273. https://doi.org/10.1108/17515631211286100

OECD. (2012). Better Skills, Better Jobs, Better Lives: A Strategic Approach to Skills Policies. Paris: OECD Publishing. https://doi.org/10.1787/9789264177338-en

Osman, A.Z.M.R., \& Ashraf, M. A. (2014). A Quality Probe of the Private MBA Program: Evidence from Bangladesh. Journal of Education and Practice, 5(23), 58-66.

Palacio, A. B., Meneses, G. D., \& Pérez, P. J. P. (2002). The configuration of the university image and its relationship with the satisfaction of students. Journal of Educational Administration, 40(5), 486-505. https://doi.org/10.1108/09578230210440311

Parasuraman, A., Zeithaml, V.A., \& Berry, L.L. (1988). SERVQUAL: A multiple-item scale for measuring consumer perceptions of service quality. Journal of Retailing, 64(1), 12-40.

Parasuraman, A., Zeithaml, V.A., \& Berry, L.L. (1985). A conceptual model of service quality and its implications for future research. Journal of Marketing, 49, 41-50. https://doi.org/10.1177/002224298504900403 
Parves, S., \& Ho, Y. W. (2012). Service quality in a higher education context: an integrated model. Asia Pacific Journal of Marketing and Logistics, 24(5), 755-784. https://doi.org/10.1108/13555851211278196

Passow, T., Fehlmann, R., \& Grahlow, H. (2005). Country reputation - from measurement to management: The case of Liechtenstein. Corporate Reputation Review, 7(4), 309-326. https://doi.org/10.1057/palgrave.crr.1540229

Petruzzellis, L., D’Uggento, A. M., \& Romanazzi, S. (2006). Student Satisfaction and Quality of Service in Italian Universities. Managing Service Quality, 16(4), 349-364. https://doi.org/10.1108/09604520610675694

Richard, M. D., \& Allaway, A. W. (1993). Service quality attributes and choice behavior. Journal of Service Marketing, 7(1), 59-68. https://doi.org/10.1108/08876049310026105

Teo, T. S. H., Srivastava, S. C., \& Jiang, L. (2008). Trust and electronic government success: an empirical study. Journal of Management Information Systems, 25(3), 99-132. https://doi.org/10.2753/MIS0742-1222250303

Topalian, A. (1984). Corporate identity: beyond the visual overstatements. International Journal of Advertising Research, 3(1), 55-62. https://doi.org/10.1080/02650487.1984.11105000

The Sun Daily. (2015). Malaysia has one of the highest proportions of international students pursuing higher education. January 29, Malaysia.

Waugh, R. F. (2002). Academic staff perceptions of administrative quality at universities. Journal of Educational Administration, 4O(2), 172-188. https://doi.org/10.1108/09578230210421123

Weerasinghe, I. M. S., \& Farnando, S. R. L. (2017). Students' satisfaction in higher education: Literature Review. American Journal of Educational Research, 5(5), 533-539.

Yeoh, O. C. (2016). Promoting Malaysia as the Region's Education Hub of Choice. Learning Curve, April 12, Kuala Lumpur, Malaysia.

Zainudin, A. (2010). The importance of corporate image in the marketing of university postgraduate programs. Asian Journal of University Education, 6(1), 13-28.

Zainudin, A. (2012). Structural equation modeling using AMOS graphics. PENERBIT PRESS, University Technology Mara.

Zikmund, W. G. (2003). Business Research Methods (7 $7^{\text {th }} e d$.). Thomson South Western Publications, Ohio, USA. 